\title{
The AHP-TOPSIS Model in the Analysis of the Counties Sustainable Development in the West Pomeranian Province in 2010 and 2017
}

\author{
Adam Stecyk $^{1}$ \\ 1 Faculty of Management and Economics of Services, University of Szczecin, Poland \\ e-mail: adam.stecyk@wzieu.pl
}

\begin{abstract}
The aim of the paper is to present the practical use of a combination involving two multicriteria methods: AHP (analytic hierarchy process) and TOPIS (The Technique for Order of Preference by Similarity to Ideal Solution), in order to expertly assess the level of sustainable development of counties in the West Pomeranian Province in 2010 and 2017. The article was divided into two main parts. The theoretical (methodological) part contains the characteristics of AHP and TOPSIS methods; in turn, the results of the analysis were presented in the empirical part. The main source of statistical data is the annual report published by Statistical Office in West Pomeranian Province, which contains the information on most important development areas (e.g. population, ecology, pollution, health, employment, macroeconomics, transport, tourism, agriculture, etc.). In other words, the purpose of the article is to build a synthetic measure of sustainable development, which will take into account socio-economic determinants for deliberately selected entities from a regional perspective. This approach will allow a detailed analysis of sustainable development according to the adopted criteria for 2010 and 2017, and may be the basis for further investigations in order to look for more complex dependencies among the factors which determine sustainable development of the studied phenomena and objects.
\end{abstract}

Keywords: sustainable development, multicriteria decision making methods, AHP, TOPSIS

\section{INTRODUCTION}

Today's enterprises, like public administration entities, operate in a dynamically changing environment, which leads to the need for a new look at the ways of conducting effective operations. Therefore, it is important to be able to indicate the scope of changes, as well as initiate the adaptation processes that enable the implementation of specific goals. Modern entities face new challenges, such as observing global and local socio-economic trends and their impact on the configuration of resources and the coordination of the processes responsible for expectations, needs and standard of living. Thus, under turbulent conditions, the concepts related to broadly understood socio-economic development play an important role, which include, among others, the development of the information society, knowledge-based economy and the concept of sustainable development.
The multifaceted nature of the issue prevails in the literature on sustainable development, (Borys, 2011), (Gasparatos, El-Haram, \& Horner, 2008), (Ness, Urbel-Piirsalu, S., \& Olsson, 2007), (Stagl, 2007), (Munda, 2006), (Wallis, 2006), (Gibson, Hassa, Holtz, Tansey, \& Whitelaw, 2005). For the purposes of this article, it is assumed that sustainable development "should be treated as a desirable environment of life and a responsible society implementing the concept of internal and intergenerational order" (Pezzey \& Toman, 2002). Another definition indicates that sustainable development is "striving to provide all living people and future generations with sufficiently high ecological, economic and socio-cultural standards, within the limits of natural tolerance, by implementing the principle of internal and intergenerational justice" (Rogall, 2010). In another approach, one can find the goals of the discussed concept: "the overall goal of sustainable development is the long-term 
stability of the economy and the environment; it is possible only thanks to the integration and recognition of economic, environmental and social problems throughout the decision-making process" (Emas, 2015).

Despite the fact that the term "sustainable development" has dominated the literature of the subject, it should be noted that several other categories should be considered along with this concept, such as: durable development, ecodevelopment, ethical development, self-sustaining development or integrated order, etc. However, regardless of the academic dispute pertaining to terminological differences, it should be emphasized that sustainable development is nowadays one of the most important concepts related to the civilizational evolution of countries and regions.

One of the important questions that arise in the context of the discussed concept is the possibility of measuring sustainable development, building computational models that enable this measurement and applying them to various entities of international, national, regional and local character. While analyzing heterogeneous approaches to sustainable development, it can be noticed that a partial answer to the problem presented in this paper, can be found in the developed theories and tools for measuring specific areas of human activity. At the international and national level, specific government and non-governmental agencies provide the statistical data and measures that illustrate specific activities of human beings. For example, such measurement tools include:

- Human Development Index, (United_Nations, 2018);

- Human Capital Index, (The_World_Bank, 2018);

- Multidimensional Poverty Index, (United_Nations, 2018);

- Sustainable Development Index, (SDSN, 2018), which consists of the measures responsible for such areas as: health, education, demography, security, ecology, economy, information society, cultural development, etc.

In the literature on the subject, one can also find the measures dedicated to specific sectors of the economy (e.g. ecology, water management, education, tourism, etc.) or original indicators describing the sustainable development in a given geographical area. (Spangenberg, Omann, \& Hinterberger, 2010), (Salgado, Quintana, Guimarães Pereira, del Moral Ituarte, \& Pedregal Mateos,
2009), (Stagl, 2007), (Munda \& Nardo, 2005), (Bell \& Morse, 2004), (Bostrom, Barke, Turaga, \& O'Connor, 2006), (Borys T. , 2014), (Roszkowska \& Filipowicz-Chomko, 2016), (Kryk, 2015), (Roszkowska, Misiewicz, \& Karwowska, 2014), (Kusideł, 2014), (Bal-Domańska \& Wilk, 2011).

This means that the construction of a dedicated, proprietary measure, reflecting the socioeconomic situation in a specific place and time is good practice connected with the measurement of sustainable development in the regional or local dimension. This outlined perspective allows to present the main goal of the article, which is the use of multicriteria decision making methods (MCDM) and the AHP-TOPSIS model to analyze the level of sustainable development of counties in the West Pomeranian Province in 2010 and 2017.

\section{METHODICAL ASSUMPTIONS AND RESEARCH PROCEDURE}

The main assumption of using multicriteria methods is to provide decision makers with a tool which, in case of many contradictory decisionmaking criteria, enables a rational decision to be made. In the literature on the subject, there is a division of MCDM methods into MODM, multiobjective decision making and MADM, multiattribute decision making). Multiobjective decision making (MODM) examines the decision problems in which the set of all acceptable decisions is a continuous set containing an infinite number of possible variants of the solution. Multiattribute decision making (MADM) focuses on the decisionmaking problems in which the set of all acceptable decisions is a discrete set containing a finite, predetermined number of possible variants of the solution (Zalewski, 2012).

T. Trzaskalik proposed a different division of multicriteria methods, distinguishing the following groups: additive methods, analytic hierarchy methods and related methods, verbal methods, the ELECTRE method group, PROMETHEE group of methods together with later variants, a group of methods using reference points, interactive methods. Regardless of the adopted classification method, the most well-known multicriteria methods include:

- ELECTRE method (Elimination et Choice Translating Reality) I and II, III and IV (Banayoun, Roy, \& Sussman, 1966); 
- SMART and SMARTER methods (Simple Multi-Attribute Ranking Technique oraz Simple Multi-Attribute Ranking Technique Exploiting Ranks) (Edwards \& Barron, 1994);

- MACBETH method (Measuring Attractiveness by a Categorical Based Evaluation TecHnique) (Bana e Costa \& Vansnick, 1999);

- PROMETHEE method (Preference Ranking Organization METHod for Enrichment Evaluations) I and II (Brans \& Vincke, 1985);

- DEA method (data envelopment analysis) (Charnes, Cooper, \& Rhodes, 1978);

- TOPIS method (The Technique for Order of Preference by Similarity to Ideal Solution) (Boutkhoum, Hanine, Agouti, \& Tikniouine, 2017), (Jahanshahloo, Hosseinzadeh Lotfi, \& Izadikhah, 1999);

- AHP/FAHP (fuzzy/analytic hierarchy process) and ANP methods (analytic network process) (Saaty, 2002).

The above-mentioned characteristics of the sustainable development concept and multicriteria decision making methods enable to present the stages of analysis and assessment of the counties sustainable development in the Western Pomeranian Province in 2010 and 2017:

1. Determination of data sources and scope of data - the data will be collected and aggregated based on the Local Data Bank of the Statistical Office in Szczecin.

2. Identification of the factors determining sustainable development of counties - selection of areas and creation of a list of determinants.

3. Determination of the research methodology the research will be carried out on the basis of multicriteria AHP and TOPSIS methods.

4. Determination of weights for individual groups of criteria and sub-criteria using the AHP method.

5. Establishing the ranking of counties for 2010 and 2017 using the TOPSIS method.

6. Comparison of changes over time.

\section{PURPOSE OF THE STUDY AND SOURCES OF DATA}

The main objective of the analysis is to answer the question about the level of the counties sustainable development in the West Pomeranian Province in 2010 and 2017 and compare changes over time. The main issue at this stage is the selection of the factors determining sustainable development and the definition of data sources. On the basis of an expert panel using heuristic methods, such as the analogous transfer method and the discovery matrix method, eight groups of determinants were proposed: demography (D), ecology (E), economy (EC), infrastructure (I), tourism (T) , culture (C), social factors (SF) and safety (S).

In the next step, the possibilities of obtaining detailed information from the Local Data Bank of the Statistical Office in Szczecin were analyzed and 46 factors responsible for the sustainable development of counties in the region were identified. In the course of the discussion, the list of factors was reduced to 33 items and grouped according to the adopted thematic areas. A detailed list of selected determinants with the description is presented in Figure 1.

The proposed list of factors is subjective and may be subject to modification. Nevertheless, it seems that the adopted factors cover the important areas of social and economic life of inhabitants and may be the basis for assessing the sustainable development of the counties. This approach to the problem indicates the need to choose the appropriate method that will enable the construction of a synthetic measuring tool. For this purpose, the AHP-TOPSIS model was proposed, which will be the basis for determining the weightings of the designated criteria (AHP) and determining the ranking of counties (TOPSIS).

\section{CHARACTERISTICS OF AHP AND TOPSIS METHODS}

The main assumption of the AHP method indicates the decomposition of the decision problem to the hierarchical structure (Figure 1) and the selection of the optimal variant under given conditions, according to the adopted criteria and their weights. The analysis is based on a relative scale of pairwise comparisons. Depending on the experience and knowledge of experts about the problem being investigated, pairwise comparisons are possible using the fundamental numerical scale (AHP) and the scale of fuzzy numbers (FAHP).

While assessing the level of sustainable development characterzing the considered counties, the AHP method was used to determine the weights of the eight groups of assessment criteria, and then the individual factors (sub-criteria) within a given group. The discussion of the level of alternatives 
Table 1. List of factors determining the level of sustainable development

\begin{tabular}{|c|c|}
\hline Group & Determinants \\
\hline Demography & $\begin{array}{l}\text { D1 - population per } 1 \mathrm{~km}^{2} ; \\
\text { D2 - natural increase per } 1000 \text { population; } \\
\text { D3 - deaths of infants per } 1000 \text { live births. }\end{array}$ \\
\hline Ecology & $\begin{array}{l}\text { E1 - water withdrawal for needs of the national economy and population per } 1 \mathrm{~km}^{2} \text { in } \mathrm{dam}^{3} ; \\
\text { E2 -industrial and municipal wastewater treated in \% of waste requiring treatment; } \\
\text { E3 - population connected to wastewater treatment plants in \% of total population; } \\
\text { E4 - emission of dust air pollutants from plants of significant nuisance to air quality in tonnes; } \\
\text { E5 - emission of gas air pollutants from plants of significant nuisance to air quality in tonnes. }\end{array}$ \\
\hline Economy & $\begin{array}{l}\text { EC1 - sold production of industry (current prices) in PLN million; } \\
\text { EC2 - revenues of county budgets per capita; } \\
\text { EC3 - expenditure of county budgets per capita; } \\
\text { EC4 - capital expenditures in enterprises by investment location (current prices) per capita; } \\
\text { EC5 - registered unemployment rate in\%; } \\
\text { EC6 - average monthly gross wages and salaries in PLN. }\end{array}$ \\
\hline Infrastructure & $\begin{array}{l}\text { I1 - water supply distribution network for } 100 \mathrm{~km}^{2} \text { in } \mathrm{km} \\
\mathrm{I} \text { - sewage distribution network a } 100 \mathrm{~km}^{2} \text { in } \mathrm{km} ; \\
\text { I3 - gas distribution network a } 100 \mathrm{~km}^{2} \text { in } \mathrm{km} \text {; } \\
14 \text { - dwellings for } 1000 \text { people. }\end{array}$ \\
\hline Tourism & $\begin{array}{l}\text { T1 - area with special natural values legally protected per } 1 \text { inhabitant in } \mathrm{m}^{2} \text {; } \\
\text { T2 - monuments of nature in the arts; } \\
\text { T3 - bicycle paths in } \mathrm{km} ; \\
\text { T4 - Woodiness in } \% \text {; } \\
\text { T5 - accommodation; } \\
\text { T6 - accommodation provided. }\end{array}$ \\
\hline Culture & $\begin{array}{l}\text { C1 - book collection in volumes per } 1000 \text { population; } \\
\text { C2 - borrowing the book collection in volumes per } 1000 \text { population; } \\
\text { C3 - viewers in permanent cinemas during the year per } 1000 \text { population. }\end{array}$ \\
\hline Social factors & $\begin{array}{l}\text { SF1 - children in kindergartens for } 100 \text { places; } \\
\text { SF2 - beds in general hospitals for } 10,000 \text { population; } \\
\text { SF3 - population per } 1 \text { entity of ambulatory health care; } \\
\text { SF4 - population per } 1 \text { accessible pharmacy. }\end{array}$ \\
\hline Safety & $\begin{array}{l}\text { S1 - offenses detected by the police in completed preparatory proceedings for } 10,000 \text { population; } \\
\text { S2 - detection rate of offenders identified by the police in } \% \text {. }\end{array}$ \\
\hline
\end{tabular}

has been omitted, because it is irrelevant to the problem under study.

The first stage of applying the AHP method is the assessment of the significance of groups of criteria by pairwise comparisons using the fundamental Saaty scale 1,3,5,7,9 (for intermediate grades it is possible to use even values $2,4,6,8$,
Figure 2) The main purpose of pairwise comparisons is to determine how many times a given item outweighs another in relation to the criterion being assessed. For the objects that prevail (in the expert's opinion), a numerical value from the Saaty scale is assigned; for objects that are predominant - the inverse of this value is given (e.g. strong

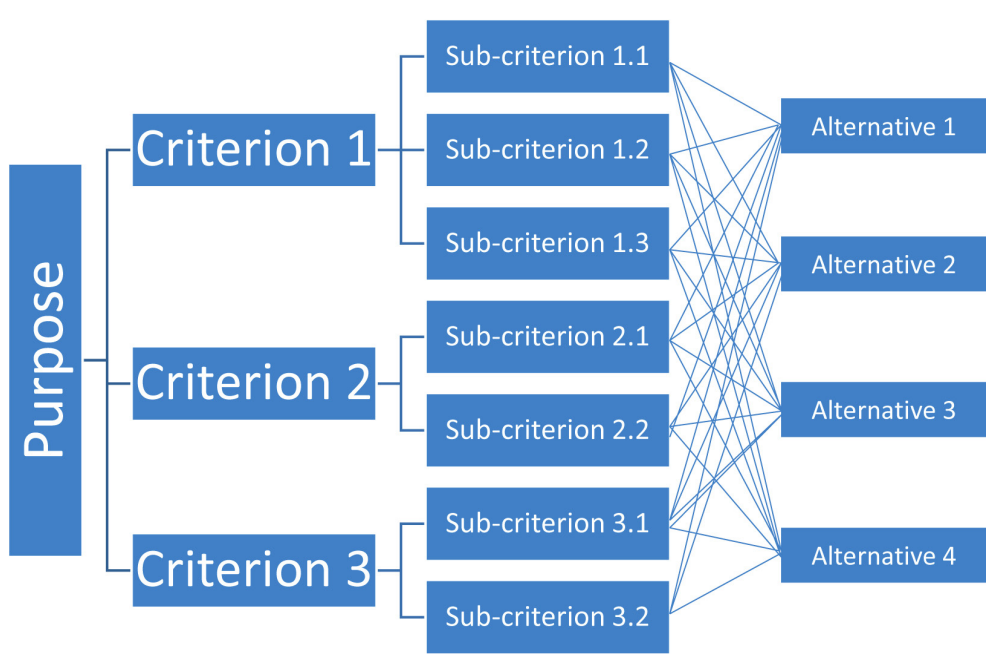

Figure 1. Decision hierarchy in AHP/FAHP method 


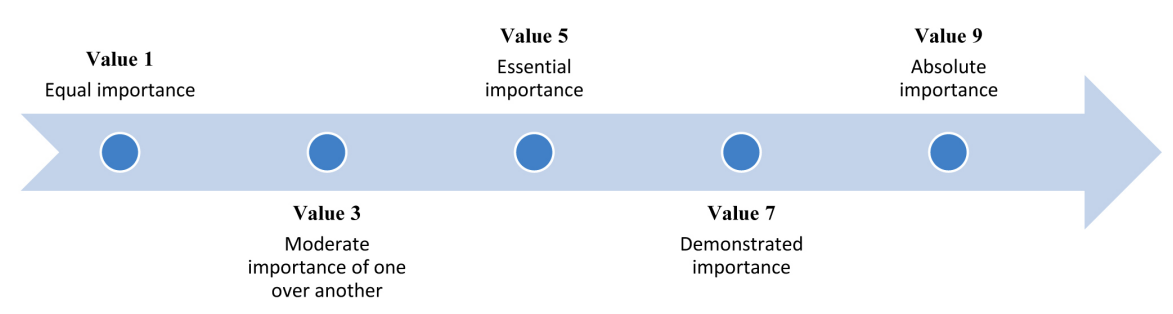

Figure 2. The fundamental scale for pairwise comparisons (Saaty, 2002; Boutkhoum et al., 2017)

advantage of criterion K1 over K2 - score 5 and at the same time strong subordination of criterion $\mathrm{K} 2$ to $\mathrm{K} 1$ - score $1 / 5$ ).

In the case of expert group assessments, there is the problem of aggregating individual opinions to the final form, which is most often achieved by applying a geometric mean to all expert assessments.

The next stages of using the AHP method are based on the calculation of a normalized matrix for the selected criteria and the largest own size of the $\lambda_{\max }$ matrix. The author of the method proved that pairwise comparisons are all the more consistent, when the $\lambda_{\text {max }}$ value is similar to the number of matrix elements $n$. On this basis, the calculation of the C.I consistency index was proposed, according to the formula 1 :

$$
\text { C.I. }=\frac{\lambda_{\max }-n}{n-1}
$$

and consistency ratio C.R. (formula 2),

$$
\text { C.R. }=\frac{100 \% * C . I .}{R . I .}
$$

where R.I is a random consistency index, generated from several thousand matrices and proposed by the author in the form of Table 2.

It is assumed that the value of C.R. for matrix $(3 \times 3)$ and $(4 \times 4)$, should be adequate accordingly, less than or equal to $5 \%$ and $8 \%$, while for larger matrices it should not exceed $10 \%$ (C.R. $\leq 10 \%)$. In that case, the consistency ratio C.R. is accepted, and the comparisons made are considered consistent. If $10 \%$ is exceeded by the C.R., the criteria evaluation should be repeated in order to eliminate the incompatibility of comparisons in pairs.
The result of the conducted analysis is obtaining the weights for individual criteria (groups). Then, the whole procedure is repeated for all sub-criteria within a given group, which results in the so-called local priorities of sub-criteria (e.g. weights for sub-criteria). The last step is to calculate the values of global priorities (weights for sub-criteria including the weights for groups of criteria). The conducted analysis using the AHP method, factors determining the sustainable development of counties, results in the weight of all 33 selected criteria.

The second of the multicriteria methods used in the discussed example, is the TOPSIS method, which consists in determining the distance of the analyzed counties from the so-called ideal and anti-ideal solutions for each factor. It results in a final, synthetic indicator that allows the creation of a ranking of the surveyed entities. The best element in the study is the one whose distance from the ideal solution is the smallest and at the same time has the largest distance from the anti-ideal solution. The use of the TOPSIS method includes the following steps:

1. Determination of weights for selected criteria; in the analyzed example, the criteria weights were determined using the AHP method.

2. Establishment of a standardized data matrix according to formula 3 .

$$
z_{i j}=\frac{x_{i j}}{\sqrt{\sum_{i=1}^{n} x_{i j}^{2}}}
$$

where: $i=1,2, \ldots, m$ and $\mathrm{j}=1,2, \ldots, n$

$z$ - normalized value, $x$ - primary value

Table 2. Consistency indices for a randomly generated matrix (Saaty, 2002)

\begin{tabular}{|c|c|c|c|c|c|c|c|c|c|c|c|c|c|c|c|}
\hline $\mathrm{n}$ & 1 & 2 & 3 & 4 & 5 & 6 & 7 & 8 & 9 & 10 & 11 & 12 & 13 & 14 & 15 \\
\hline R.I. & 0 & 0 & 0.52 & 0.89 & 1.11 & 1.25 & 1.35 & 1.40 & 1.45 & 1.49 & 1.52 & 1.54 & 1.56 & 1.58 & 1.59 \\
\hline
\end{tabular}


3. Taking into account weights according to formula 4:

$$
\jmath_{i j}=w_{j} \otimes z_{i j}
$$

where: $V_{i j}$ - normalized weighted value

4. Determining the value of the ideal solution $\mathrm{Vj}^{+}$ and anti ideal $\mathrm{Vj}^{-}$:

- for beneficial criteria: $\mathrm{Vj}^{+}$- maximum value for a given criterion, $\mathrm{Vj}^{-}-$minimum value for a given criterion.

- for non-beneficial (cost) criteria: $\mathrm{Vj}^{+}-$minimum value for a given criterion, $\mathrm{Vj}^{-}-$maximum value for a given criterion.

5. Calculation of the Euclidean distance of the tested objects from the ideal (formula 5) and anti-ideal solution (formula 6):

$$
\begin{gathered}
S_{i}^{+}=\sqrt{\sum_{j=1}^{n}\left(v_{i j}-a_{j}^{+}\right)^{2}} \\
S_{i}^{-}=\sqrt{\sum_{j=1}^{n}\left(v_{i j}-a_{j}^{i}\right)^{2}}
\end{gathered}
$$

where: $i=1,2, \ldots, m$ and $j=1,2, \ldots, n$

6. Calculation of the performance score $\mathrm{R}_{\mathrm{i}}$ for the examined objects, according to formula 7 :

$$
R_{i}=\frac{S_{i}^{-}}{S_{i}^{+}+S_{i}^{-}}
$$

The performance score $\mathrm{R}_{\mathrm{i}}$ of the highest value are the best solution (the best county with the highest level of sustainable development for a given year) in the considered problem of linear ordering (ranking).
The use of the AHP method enables to obtain weights for the accepted factors determining sustainable development both in 2010 and in 2017. Creating a ranking for 2010 and 2017 using the TOPSIS method requires two independent analyses (for the two analyzed years).

\section{Determination of weights for criteria and sub-criteria (AHP)}

The first step of the analysis was to build a pairwise comparison matrix (Table 3), according to the fundamental scale 1-9 for the AHP method (the aggregation of values assigned by experts was made using the geometric mean). Then, in order to check the compliance of the criteria, a normalized matrix was built (figure 6) and the largest own size of the $\lambda_{\text {max }}$ matrix, which amounted to 8.70 , was calculated. Next, the consistency index C.I $=0.1001$ and the consistency ratio were calculated (for eight groups of criteria $(n=8)$, R.I $=1.40)$ C.R $=0.0715$ (7.15\%). Thus, it can be assumed - in accordance with the adopted AHP method - that the consistency ratio may be accepted (is less than 10\%), which means that the comparisons made under the adopted criteria are consistent.

The next stage was to build a matrix of comparisons and a standardized matrix for sub-criteria in the first group of criteria (Demography). Then, the conformity of comparisons was verified by calculating the value of the consistency index and the consistency ratio within a given group. If C.R $<=10 \%$ were obtained, the results were accepted and the entire procedure was performed for the next sub-criteria group (the comparison procedure was performed 8 times for 8 groups of subcriteria). Due to the limited form of the study, the article presents an example of calculations for the first group of sub-criteria, i.e. Demography.

Table 3. Matrix of pairwise comparison for selected criteria

\begin{tabular}{|c|c|c|c|c|c|c|c|c|}
\hline Criterion & $\mathrm{D}$ & $\mathrm{E}$ & $\mathrm{EC}$ & $\mathrm{I}$ & $\mathrm{T}$ & $\mathrm{C}$ & $\mathrm{SF}$ & $\mathrm{S}$ \\
\hline $\mathrm{D}$ & 1.00 & 0.50 & 0.33 & 1.00 & 2.00 & 2.00 & 1.00 & 1.00 \\
\hline E & 2.00 & 1.00 & 1.00 & 2.00 & 1.00 & 1.00 & 2.00 & 1.00 \\
\hline EC & 3.00 & 1.00 & 1.00 & 3.00 & 2.00 & 2.00 & 3.00 & 2.00 \\
\hline I & 1.00 & 0.50 & 0.33 & 1.00 & 4.00 & 0.50 & 0.50 & 0.33 \\
\hline T & 0.50 & 1.00 & 0.50 & 0.25 & 1.00 & 0.50 & 1.00 & 0.33 \\
\hline C & 0.50 & 1.00 & 0.50 & 2.00 & 2.00 & 1.00 & 2.00 & 1.00 \\
\hline SF & 1.00 & 0.50 & 0.33 & 2.00 & 1.00 & 0.50 & 1.00 & 1.00 \\
\hline S & 1.00 & 1.00 & 0.50 & 3.00 & 3.00 & 1.00 & 1.00 & 1.00 \\
\hline
\end{tabular}


Table 4. Normalized matrix of pairwise comparison for selected criteria

\begin{tabular}{|c|c|c|c|c|c|c|c|c|c|}
\hline Criterion & $\mathrm{D}$ & $\mathrm{E}$ & $\mathrm{EC}$ & $\mathrm{I}$ & $\mathrm{T}$ & $\mathrm{C}$ & $\mathrm{SF}$ & $\mathrm{S}$ & Weights \\
\hline $\mathrm{D}$ & 0.10 & 0.08 & 0.07 & 0.07 & 0.13 & 0.24 & 0.09 & 0.13 & $11.24 \%$ \\
\hline E & 0.20 & 0.15 & 0.22 & 0.14 & 0.06 & 0.12 & 0.17 & 0.13 & $15.01 \%$ \\
\hline EC & 0.30 & 0.15 & 0.22 & 0.21 & 0.13 & 0.24 & 0.26 & 0.26 & $22.11 \%$ \\
\hline I & 0.10 & 0.08 & 0.07 & 0.07 & 0.25 & 0.06 & 0.04 & 0.04 & $8.96 \%$ \\
\hline T & 0.05 & 0.15 & 0.11 & 0.02 & 0.06 & 0.06 & 0.09 & 0.04 & $7.30 \%$ \\
\hline K & 0.05 & 0.15 & 0.11 & 0.14 & 0.13 & 0.12 & 0.17 & 0.13 & $12.53 \%$ \\
\hline SF & 0.10 & 0.08 & 0.07 & 0.14 & 0.06 & 0.06 & 0.09 & 0.13 & $9.13 \%$ \\
\hline S & 0.10 & 0.15 & 0.11 & 0.21 & 0.19 & 0.12 & 0.09 & 0.13 & $13.73 \%$ \\
\hline
\end{tabular}

Table 5. Matrix of pairwise comparison for demography group

\begin{tabular}{|c|c|c|c|}
\hline Sub-criterion & D1 & D2 & D3 \\
\hline D1 & 1.00 & 3.00 & 5.00 \\
\hline D2 & 0.33 & 1.00 & 4.00 \\
\hline D3 & 0.20 & 0.25 & 1.00 \\
\hline
\end{tabular}

For the sub-criteria from the Demography group, a pairwise comparison matrix (Table 5) and a normalized matrix with weights (Table 8 ) were created. Then, the following parameters were calculated: largest own size of the $\lambda_{\text {max }}$ matrix $=3.09$; the consistency index C.I $=0.0433$ and the consistency ratio (for 3 sub-criteria $(n=3)$, R.I $=0.52$ ) C.R $=0.0833(8.33 \%)$. The consistency ratio was accepted, which means acceptance of the weights calculated in the normalized matrix for the given group.

The final stage in this part of the analysis was to obtain the values of global priorities, i.e. weights for all sub-criteria, including the weights assigned to particular groups of criteria. The summary of results is shown in Table 7.

\section{The county ranking for 2017 and 2010 (TOPSIS)}

The calculation of weights for all identified factors determining the level of counties sustainable development allows joining the next stage of analysis, involving the use of the TOPIS method to build a ranking of counties in the West Pomeranian Province in 2017. Due to the extensive empirical

Table 6. Normalized matrix of pairwise comparison for demography group

\begin{tabular}{|c|c|c|c|c|}
\hline Sub-criterion & D1 & D2 & D3 & Weights \\
\hline D1 & 0.65 & 0.71 & 0.50 & 0.62 \\
\hline D2 & 0.22 & 0.24 & 0.40 & 0.28 \\
\hline D3 & 0.13 & 0.06 & 0.10 & 0.10 \\
\hline
\end{tabular}

material, only the selected elements of the analysis at individual stages will be presented.

An important element in the conducted study is to understand the nature of the proposed assessment criteria, which may take the characteristics of beneficial and non-beneficial (cost) criteria. In general terms, it can be assumed that the desirable values for beneficial criteria are the values aiming at the maximum, and cost criteria - the values aiming at 0 . There are also factors that can be considered beneficial to a certain level of value, and exceeding this level they take on a non-beneficial character. In the analyzed example, the factor D2 population growth, was defined as a beneficial criterion. In the case of factor D3 - deaths of infants per 1000 live births, the cost criteria was assumed.

It is also worth mentioning that factorsmay take on both characteristics, depending on the adopted assumptions. An example is E1 - water withdrawal for needs of the national economy and population per $1 \mathrm{~km}^{2}$ in $\mathrm{dm}^{3}$. From the point of view of the sustainable development of a county regarding the water consumption, this determinant was defined as non-beneficial criteria. However, one can imagine a study in which the level of production efficiency will be analyzed, for which the water intake at a given time and place can be described as beneficial.

In the analyzed example, the following factors were assumed to be non-beneficial (the remaining ones are beneficial): D3 - deaths of infants per 1000 live births, E1 - water withdrawal for needs of the national economy and population per $1 \mathrm{~km}^{2}$ in $\mathrm{dm}^{3}, \mathrm{E} 4$ - emission of dust air pollutants from plants of significant nuisance to air quality in tonnes; E5 - emission of gas air pollutants from plants of significant nuisance to air quality in tonnes, G5 - registered unemployment rate in \%, B1 - offenses detected by the police in completed preparatory proceedings for 10,000 population.

On the basis of the assumptions above, a matrix was created in which all counties of the West 
Table 7. Final weights for all the criteria for assessing the sustainable development of counties

\begin{tabular}{|c|c|c|c|}
\hline determinant & $\begin{array}{c}\text { group } \\
\text { weight }\end{array}$ & $\begin{array}{c}\text { sub-criterion } \\
\text { weight }\end{array}$ & $\begin{array}{c}\text { final } \\
\text { weight }\end{array}$ \\
\hline D1 & $11.24 \%$ & $61.94 \%$ & $6.96 \%$ \\
\hline D2 & $11.24 \%$ & $28.42 \%$ & $3.19 \%$ \\
\hline D3 & $11.24 \%$ & $9.64 \%$ & $1.08 \%$ \\
\hline E1 & $15.01 \%$ & $16.75 \%$ & $2.51 \%$ \\
\hline E2 & $15.01 \%$ & $22.12 \%$ & $3.32 \%$ \\
\hline E3 & $15.01 \%$ & $28.75 \%$ & $4.32 \%$ \\
\hline E4 & $15.01 \%$ & $16.98 \%$ & $2.55 \%$ \\
\hline E5 & $15.01 \%$ & $15.40 \%$ & $2.31 \%$ \\
\hline EC1 & $22.11 \%$ & $12.65 \%$ & $2.80 \%$ \\
\hline EC2 & $22.11 \%$ & $15.23 \%$ & $3.37 \%$ \\
\hline EC3 & $22.11 \%$ & $15.67 \%$ & $3.46 \%$ \\
\hline EC4 & $22.11 \%$ & $17.89 \%$ & $3.96 \%$ \\
\hline EC5 & $22.11 \%$ & $17.34 \%$ & $3.83 \%$ \\
\hline EC6 & $22.11 \%$ & $21.22 \%$ & $4.69 \%$ \\
\hline I1 & $8.96 \%$ & $24.36 \%$ & $2.18 \%$ \\
\hline I2 & $8.96 \%$ & $23.78 \%$ & $2.13 \%$ \\
\hline I3 & $8.96 \%$ & $22.60 \%$ & $2.03 \%$ \\
\hline I4 & $8.96 \%$ & $29.26 \%$ & $2.62 \%$ \\
\hline T1 & $7.30 \%$ & $23.23 \%$ & $1.70 \%$ \\
\hline T2 & $7.30 \%$ & $11.56 \%$ & $0.84 \%$ \\
\hline T3 & $7.30 \%$ & $16.64 \%$ & $1.22 \%$ \\
\hline T4 & $7.30 \%$ & $22.90 \%$ & $1.67 \%$ \\
\hline T5 & $7.30 \%$ & $15.78 \%$ & $1.15 \%$ \\
\hline T6 & $7.30 \%$ & $9.89 \%$ & $0.72 \%$ \\
\hline C1 & $12.53 \%$ & $36.12 \%$ & $4.53 \%$ \\
\hline C2 & $12.53 \%$ & $29.10 \%$ & $3.65 \%$ \\
\hline C3 & $12.53 \%$ & $34.78 \%$ & $4.36 \%$ \\
\hline SF1 & $9.13 \%$ & $30.64 \%$ & $2.80 \%$ \\
\hline SF2 & $9.13 \%$ & $23.56 \%$ & $2.15 \%$ \\
\hline SF3 & $9.13 \%$ & $25.32 \%$ & $2.31 \%$ \\
\hline SF4 & $9.13 \%$ & $20.48 \%$ & $1.87 \%$ \\
\hline S2 & $13.73 \%$ & $42.67 \%$ & $5.86 \%$ \\
\hline & $13.73 \%$ & $57.33 \%$ & $7.87 \%$ \\
\hline & & $100.00 \%$ \\
\hline
\end{tabular}

Pomeranian Province were described by empirical data for 33 factors determining sustainable development in 2017. A summary of data for the counties of the Koszalin Region and demographic and ecological factors were presented in Table 8. The normalized data for the counties of the Koszalin Region and demographic and ecological factors were presented in Table 9. Table 10 contains normalized weighted data (according to weights obtained through the AHP method) for the same part of the analysis.

The next stage of the analysis was to calculate the Euclidean distances of the studied entities from the ideal $\mathrm{S}^{+}$and anti-ideal $\mathrm{S}^{-}$solutions, and then the performance score $\mathrm{R}_{\mathrm{i}}$ for each county. The results were presented in a descending system, according to the $\mathrm{R}_{\mathrm{i}}$, which allowed to organize the counties of the West Pomeranian Province from the highest level of sustainable development to the lowest level in 2017 (Table 11).

The final stage of the analysis was to repeat the whole research procedure using the TOPSIS method for empirical data from 2010. The results of the analysis, i.e. the ranking of counties according to the same criteria (and designated weights), are presented in Table 12. A detailed sensitivity analysis, consisting in searching for the information about the ranking development with changed weight proportions for the selected criteria, goes beyond the scope of this study.

However, it is worth comparing the changes in the ranking of particular counties by analyzing the years 2010 and 2017 (Table 13). To this end, the following characteristics were proposed for describing trends of changes in relation to sustainable development and thus changing the ranking position:

- Growing tendency: significant promotion, promotion and slight promotion;

- No change;

- Decreasing trend: slight decline, decline and significant decline.

The leader of the rankings in the two analyzed periods is the city of Koszalin; in the second place is the city of Szczecin and thus the assessment of the level of sustainable development of both counties is positive. The next group includes counties: policki, city of Świnoujście, goleniowski, kolobrzeski and koszaliński. These entities belong to the group occupying the 3-7 place and, depending on the analyzed period, are characterized by a good level of sustainable development in relation to other counties. Then, a special group should be indicated, the members of which significantly improved their position in the ranking within seven years and which can be classified as a group with a sufficient level of sustainable development compared to other entities.

These are the counties: stargardzki (change from 19 to 10), sławieński (change from 13 to 8) and walecki (from 14 to 9). The next group are the counties in the second ten of the ranking, including: choszczeński, drawski, szczecinecki and kamieński. The remaining counties are included in the group requiring in-depth analysis, as they are located at the bottom of the table of both rankings and are characterized by a decreasing tendency 
Table 8. Empirical data for selected criteria for assessing the sustainable development of counties in the Koszaliński Region

\begin{tabular}{|l|c|c|c|c|c|c|c|c|c|c|}
\hline \multicolumn{1}{|c|}{ County/Criterion } & D1 & D2 & D3 & E1 & E2 & E3 & E4 & E5 \\
\hline \multicolumn{7}{|c|}{ Koszaliński Region } \\
\hline Białogardzki & 57 & -1.4 & 2.2 & 8.7 & 100.0 & 85.9 & 0.1 & 151.6 \\
\hline Kołobrzeski & 110 & -0.9 & 2.8 & 10.0 & 99.9 & 93.8 & 0.0 & 79.4 \\
\hline Koszaliński & 40 & 0.4 & 3.0 & 4.8 & 99.6 & 59.3 & 0.0 & 18.6 \\
\hline Sławieński & 54 & -0.3 & 5.4 & 3.6 & 100.0 & 66.6 & 0.0 & 28.3 \\
\hline Koszalin & 1099 & -0.3 & 4.6 & 31.9 & 100.0 & 100.0 & 0.2 & 124.0 \\
\hline
\end{tabular}

Table 9. Normalized values for selected criteria for assessing the sustainable development of counties in the Koszaliński Region

\begin{tabular}{|c|c|c|c|c|c|c|c|c|}
\hline County/Criterion & D1 & D2 & D3 & E1 & E2 & E3 & E4 & E5 \\
\hline \multicolumn{9}{|c|}{ Koszaliński Region } \\
\hline Białogardzki & 0.0323 & -0.1877 & 0.1075 & 0.0130 & 0.2189 & 0.2353 & 0.1125 & 0.0341 \\
\hline Kołobrzeski & 0.0622 & -0.1207 & 0.1368 & 0.0149 & 0.2187 & 0.2570 & 0.0000 & 0.0179 \\
\hline Koszaliński & 0.0226 & 0.0536 & 0.1466 & 0.0072 & 0.2180 & 0.1624 & 0.0000 & 0.0042 \\
\hline Sławieński & 0.0306 & -0.0402 & 0.2638 & 0.0054 & 0.2189 & 0.1824 & 0.0000 & 0.0064 \\
\hline Koszalin & 0.6219 & -0.0402 & 0.2248 & 0.0475 & 0.2189 & 0.2739 & 0.2250 & 0.0279 \\
\hline
\end{tabular}

Table 10. Weighted, normalized values for selected criteria for assessing the sustainable development of counties in the Koszaliński Region

\begin{tabular}{|c|c|c|c|c|c|c|c|c|}
\hline Weights & $6.96 \%$ & $3.19 \%$ & $1.08 \%$ & $2.51 \%$ & $3.32 \%$ & $4.32 \%$ & $2.55 \%$ & $2.31 \%$ \\
\hline County/Criterion & D1 & D2 & D3 & E1 & E2 & E3 & E4 & E5 \\
\hline \multicolumn{9}{|c|}{ Koszaliński Region } \\
\hline Białogardzki & 0.0022 & -0.0060 & 0.0012 & 0.0003 & 0.0073 & 0.0102 & 0.0029 & 0.0008 \\
\hline Kołobrzeski & 0.0043 & -0.0039 & 0.0015 & 0.0004 & 0.0073 & 0.0111 & 0.0000 & 0.0004 \\
\hline Koszaliński & 0.0016 & 0.0017 & 0.0016 & 0.0002 & 0.0072 & 0.0070 & 0.0000 & 0.0001 \\
\hline Sławieński & 0.0021 & -0.0013 & 0.0029 & 0.0001 & 0.0073 & 0.0079 & 0.0000 & 0.0001 \\
\hline Koszalin & 0.0433 & -0.0013 & 0.0024 & 0.0012 & 0.0073 & 0.0118 & 0.0057 & 0.0006 \\
\hline
\end{tabular}

(decline or significant decline). It is necessary to indicate such counties as: pyrzycki, białogardzki (the largest decrease in the ranking by 12 positions), gryficki, myślborski (decrease by 10), świdwiński (promotion by 1 position from 20 to 19), łobeski and gryfiński (no changes, last places in both rankings).

\section{CONCLUSIONS}

The proposed research model, taking into account the AHP-TOPSIS methodology and expert selection of factors determining the level of sustainable development of counties in the West Pomeranian Province, allows a broad look at the problem of civilization, social and economic growth in the regional system and may be the basis for further, in-depth analyses and scientific discussions. A detailed analysis of the conducted study based on the adopted methodological assumptions indicates a number of important issues related to both the use of multicriteria decision making methods in scientific research and the application of the concept of sustainable development to local and regional entities. The most important of them include:

1. In conceptual terms - the problem of defining sustainable development for entities with different characteristics. The problem of selecting the factors determining the level of sustainable development for entities of a global, continental, national, regional and local character. From this point of view, the proposed 33 factors constitute a subjectively selected set, which may be subject to certain modifications, depending on the nature and purpose of the analysis. At the same time, it can be assumed that the proposed 
Table 11. Ranking of counties of the West Pomeranian Region in 2017 according to selected criteria defining the level of sustainable development

\begin{tabular}{|l|l|c|c|c|}
\hline No. & \multicolumn{1}{|c|}{ County } & $\mathrm{S}+$ & $\mathrm{S}-$ & $\mathrm{R}_{\mathrm{i}}$ \\
\hline & Koszalin & 0.0392 & 0.0743 & 0.6544 \\
\hline & Szczecin & 0.0625 & 0.0690 & 0.5246 \\
\hline & Policki & 0.0655 & 0.0676 & 0.5077 \\
\hline & Świnoujście & 0.0683 & 0.0647 & 0.4865 \\
\hline & Goleniowski & 0.0691 & 0.0616 & 0.4711 \\
\hline & Kołobrzeski & 0.0695 & 0.0608 & 0.4667 \\
\hline & Koszaliński & 0.0734 & 0.0615 & 0.4561 \\
\hline & Sławieński & 0.0740 & 0.0611 & 0.4523 \\
\hline & Wałecki & 0.0744 & 0.0613 & 0.4516 \\
\hline & Stargardzki & 0.0704 & 0.0576 & 0.4501 \\
\hline & Choszczeński & 0.0751 & 0.0609 & 0.4476 \\
\hline & Drawski & 0.0752 & 0.0606 & 0.4461 \\
\hline & Szczecinecki & 0.0720 & 0.0579 & 0.4457 \\
\hline & Kamieński & 0.0753 & 0.0599 & 0.4433 \\
\hline & Pyrzycki & 0.0763 & 0.0601 & 0.4409 \\
\hline & Białogardzki & 0.0750 & 0.0588 & 0.4393 \\
\hline & Gryficki & 0.0750 & 0.0586 & 0.4387 \\
\hline & Myśliborski & 0.0739 & 0.0577 & 0.4385 \\
\hline & Świdwiński & 0.0756 & 0.0590 & 0.4383 \\
\hline & Łobeski & 0.0777 & 0.0596 & 0.4343 \\
\hline & Gryfiński & 0.0793 & 0.0503 & 0.3878 \\
\hline & & & & \\
\hline
\end{tabular}

model can constitute a pattern of comparisons for counties in Poland in the second and third decade of the 21 st century.

2. In the methodological aspect - the problem of measuring key determinants, the problem of compatibility of measurements carried out by various entities with similar characteristics and the problem of comparisons between entities. The problem of data reliability (quality) and the problem of data collection by various research institutions are a separate issue.

3. In the methodological aspect - the problem of selecting a research model, and in particular the problem of choosing multicriteria decision making methods to analyze the weights of selected criteria and the problem of linear ordering. This perspective requires emphasizing the special role of knowledge and experience of experts who evaluate factors, e.g. based on reversible pairwise comparisons. This means that the competences of individual experts are of great importance for determining the purpose of the analysis (hierarchy of problems), selection of methods, and thus for the final results of the study.

4. In terms of methodology - the methodology proposed is based on a combination of two methods: AHP and TOPSIS. The question
Table 12. Ranking of counties of the West Pomeranian Province in 2010 according to selected criteria defining the level of sustainable development

\begin{tabular}{|l|l|c|c|c|}
\hline No. & \multicolumn{1}{|c|}{ County } & $\mathrm{S}+$ & $\mathrm{S}-$ & $\mathrm{R}_{\mathrm{i}}$ \\
\hline & Koszalin & 0.0346 & 0.0740 & 0.6812 \\
\hline & Szczecin & 0.0603 & 0.0691 & 0.5341 \\
\hline & Świnoujście & 0.0638 & 0.0641 & 0.5013 \\
\hline & Białogardzki & 0.0676 & 0.0612 & 0.4750 \\
\hline & Kołobrzeski & 0.0648 & 0.0575 & 0.4703 \\
\hline & Goleniowski & 0.0667 & 0.0591 & 0.4699 \\
\hline & Policki & 0.0659 & 0.0572 & 0.4644 \\
\hline & Myśliborski & 0.0680 & 0.0580 & 0.4605 \\
\hline & Koszaliński & 0.0693 & 0.0590 & 0.4600 \\
\hline & Choszczeński & 0.0708 & 0.0598 & 0.4577 \\
\hline & Gryficki & 0.0698 & 0.0585 & 0.4560 \\
\hline & Pyrzycki & 0.0710 & 0.0595 & 0.4560 \\
\hline & Sławieński & 0.0704 & 0.0589 & 0.4556 \\
\hline & Wałecki & 0.0703 & 0.0588 & 0.4554 \\
\hline & Drawski & 0.0709 & 0.0589 & 0.4539 \\
\hline & Łobeski & 0.0727 & 0.0589 & 0.4474 \\
\hline & Szczecinecki & 0.0704 & 0.0565 & 0.4454 \\
\hline & Kamieński & 0.0721 & 0.0576 & 0.4440 \\
\hline & Stargardzki & 0.0685 & 0.0535 & 0.4388 \\
\hline & Świdwiński & 0.0740 & 0.0570 & 0.4351 \\
\hline & Gryfiński & 0.0770 & 0.0470 & 0.3791 \\
\hline & & & & \\
\hline
\end{tabular}

arises about the possibility of modifying the computational model both as to the method used (e.g. the use of fuzzy numbers in the FAHP hierarchical analysis and the use of fuzzy FTOPSIS analysis) and in the selection of the method itself (e.g. using the CRITIC method to establish the weighting criteria and the PROMETHEE II or VIKOR method to creating a ranking of counties).

It should be noted that the analysis and assessment of the level of sustainable development of specific entities (regardless of their nature) is a complex research task. The problems of identifying the factors determining sustainable development and their impact on the final result constitute a major obstacle on the path of a researcher trying to describe the socio-economic reality in a specific place and time. The solution to the above-mentioned problems may be the use of multicriteria research methods, enabling a multi-aspect description of the analyzed phenomena and objects. In the literature on the subject, many applications of multicriteria models for solving difficult socioeconomic issues can be found.

Regardless of the substantive problems (e.g. the choice of criteria) and methodical (the choice 
Table 13. List of rankings in 2010 and 2017 for counties of the West Pomeranian Province

\begin{tabular}{|l|c|c|c|l|}
\hline \multicolumn{1}{|c|}{ County } & 2010 & 2017 & Change & \multicolumn{1}{|c|}{ Description } \\
\hline Koszalin & 1 & 1 & 0 & leader. no change \\
\hline Szczecin & 2 & 2 & 0 & $\begin{array}{l}\text { vice leader. no } \\
\text { change }\end{array}$ \\
\hline Świnoujście & 3 & 4 & -1 & slight decline \\
\hline Białogardzki & 4 & 16 & -12 & significant decline \\
\hline Kołobrzeski & 5 & 6 & -1 & slight decline \\
\hline Goleniowski & 6 & 5 & 1 & slight promotion \\
\hline Policki & 7 & 3 & 4 & promotion \\
\hline Myśliborski & 8 & 18 & -10 & significant decline \\
\hline Koszaliński & 9 & 7 & 2 & slight promotion \\
\hline Choszczeński & 10 & 11 & -1 & slight decline \\
\hline Gryficki & 11 & 17 & -6 & significant decline \\
\hline Pyrzycki & 12 & 15 & -3 & decline \\
\hline Sławieński & 13 & 8 & 5 & $\begin{array}{l}\text { significant } \\
\text { promotion }\end{array}$ \\
\hline Wałecki & 14 & 9 & 5 & $\begin{array}{l}\text { significant } \\
\text { promotion }\end{array}$ \\
\hline Drawski & 15 & 12 & 3 & promotion \\
\hline Łobeski & 16 & 20 & -4 & decline \\
\hline Szczecinecki & 17 & 13 & 4 & promotion \\
\hline Kamieński & 18 & 14 & 4 & promotion \\
\hline Stargardzki & 19 & 10 & 9 & $\begin{array}{l}\text { significant } \\
\text { promotion }\end{array}$ \\
\hline Świdwiński & 20 & 19 & 1 & slight promotion \\
\hline Gryfiński & 21 & 21 & 0 & $\begin{array}{l}\text { last place. no } \\
\text { change }\end{array}$ \\
\hline
\end{tabular}

of research model) occurring in the study, the use of multicriteria methods will be increasingly applicable to the decision-makers who are responsible for local and central government policy as well as managers of commercial enterprises. Each subsequent empirical study and new computational models are a step forward in the search for, even if not ideal, certainly the best socio-economic reality description that can be the basis for social development and economic growth.

\section{REFERENCES}

1. Bal-Domańska, B., \& Wilk, J. (2011). Gospodarcze aspkety zrównoważonego rozwoju województwwielowymiarowa analza porównawcza. Przegląd Statyczny (pp. 3-4).

2. Bana e Costa, C., \& Vansnick, F. (1999). Sur la quantification des jugements de valeur: $\mathrm{L}$ 'approche Macbeth, Cahiiers du LAMSADE. Paris: Universite Paris - Dauphine.

3. Banayoun, R., Roy, B., \& Sussman, N. (1966). Manual de Reference du Programme Electre, Note de Synthese et Formation 25. Direction Scientifique SEMA.
4. Bell, S., \& Morse, S. (2004). Experiences with sustainability indicators and stakeholder participation: a case study relating to a 'Blue Plan' project in Malta. Sustain(12), 1-14.

5. Borys, T. (2011). Zrównoważony rozwój- jak rozpoznać ład zintegrowany. Problemy Ekorozwoju, 6(2), 75-81.

6. Borys, T. (2014). Wybrane problemy metodologii pomiaru nowego paradygmatu rozwoju-polskie doświadczenia. Optimum. Studia Ekomoniczne, 69(3).

7. Bostrom, A., Barke, R., Turaga, R., \& O'Connor, R. (2006). Environmental concerns and the new environmental paradigm in Bulgaria. J. Environ(37), 25-40.

8. Boutkhoum, O., Hanine, M., Agouti, T., \& Tikniouine, A. (2017). A decision-maiking approach based on fuzzy AHP-TOPSIS metodology for selecting appropriate cloud solution to manage big data. International Journal of System Assurance Engineering and Management.

9. Boutkhoum, O., Hanine, M., Agouti, T., \& Tikniouine, A. (2017). A decision-maiking approach based on fuzzy AHP-TOPSIS metodology for selecting appropriate cloud solution to manage big data. International Journal of System Assurance Engineering and Management.

10. Brans, J., \& Vincke, P. (1985). A Reference Ranking Organization Method (The PROMETHEÉ Method for Multiple Criteria Decision-Making. Management Science Vol.31.

11. Charnes, A., Cooper, W., \& Rhodes, E. (1978). Measuring the efficiency of decision making units. European Journal of the Operational Research No 2, 63-85.

12. Edwards, W., \& Barron, F. (1994). SMARTS and SMARTER: improved Simple methods for mulitiattribute measurement. Organizational behavior and human decison process, pp. 60.

13. Emas, R. (2015). The Concept of Sustainable Development: Definition and Defining Principles. Pobrano z lokalizacji Brief for GSDR2015: https://sustainabledevelopment.un.org/content/ documents/5839GSDR\%202015_SD_concept_ definiton_rev.pdf

14. Gasparatos, A., El-Haram, M., \& Horner, M. (2008). A critical review of reductionist approaches for assessing the progress towards sustainability. Enviton. Impact Assess(28), 286-311.

15. Gibson, R., Hassa, S., Holtz, S., Tansey, J., \& Whitelaw, G. (2005). Sustainability Assessment: Criteria and Processes. Earthscan.

16. Jahanshahloo, G., Hosseinzadeh Lotfi, F., \& Izadikhah, M. (1999). Extension of the TOPSIS method for decision-making problems with fuzzy data. Applied mathematics and Computation 185, 1544-1551. 
17. Kryk, B. (2015). Wybrane instytucjonalno-administracyjne uwarunkowania jakośći życia w wojewodztwie zachodniopomorskim. Optimum. Studia Ekonomiczne, 3(75).

18. Kusideł, E. (2014). Zbieżność poziomu rozwoju województw Polski w kontekscie kształtowania ładu instytucyjnego. Optimum. Studia Ekomoniczne, 3(69).

19. Munda, G. (2006). Social multi-criteria evaluation for urban sustainablilty policies. Land Use Pol(23), strony 86-94.

20. Munda, G., \& Nardo, M. (2005). Institute for the Protection and Security of the Citizen, Ispra. Constructing Consistent Composite Indicators: The Issue od Weights (EUR 21834 EN). Retrieved from Available at:http://crell.jrc.ec.europa.eu/Well-being/papers/Munda $\% 20 \mathrm{Nardo} \% 20$ euroreport $1 . p d f$

21. Ness, B., Urbel-Piirsalu, E.S.A., \& Olsson, L. (2007). Categorising tools for sustaunability assessment.

22. Pezzey, J.C., \& Toman, M.A. (2002). Progress and problems in the economics of sustainability. Great Britain: Edward Edgar Publishing.

23. Rogall, H. (2010). Ekonomia zrównowżonego rozwoju. Poznań: Zysk i S-ka Wydawnictwo.

24. Roszkowska, E., \& Filipowicz-Chomko, M. (2016). Analiza wskaźnikowa zróźnicowania rozwoju społecznego województw Polski w latach 2005-2013 w kontekscie realizacji koncepcji zrownoważonego rozwoju. Ekonomia i Środowisko(1(56)).

25. Roszkowska, E., Misiewicz, E., \& Karwowska, R. (2014). Analiza poziomu zrównoważonego rozwoju województw Polski w 2010. Ekonomia i Środowisko, 2(49).

26. Saaty, R. (2002). Decision Making in Complex En- vironments: The Analytic Network Process (ANP) for Dependence and Feedback; a manual for the ANP Software SuperDecisions. Creative Decisions Foundation,.

27. Salgado, P., Quintana, C., Guimarães Pereira, A., del Moral Ituarte, L., \& Pedregal Mateos, B. (2009). Participative multi-criteria analsis for the evaluation of water governance alternatives. A case in the Costa del Sol (Malaga), 68, 990-1005.

28. SDSN. (2018). SDG Index \& Dashboards. Pobrano z lokalizacji Sustainable development solutions network: http://unsdsn.org/

29. Spangenberg, J., Omann, \& Hinterberger, F. (2010). Sustiantable growth criteria. Minimum benchmarks and scenarios for employment and the enviromment. Ecol. Econ.

30. Stagl, S. (2007). Emerging Methods for Sustainability Valuation 813 and Appraisal. Sustainable Development Researh Network,London. Pobrano z lokalizacji Available at: http://www.sd-research. org.uk/post.php? $\mathrm{p}=129$

31. The_World_Bank. (2018). Human Capital Index. Pobrano z lokalizacji The World Bank: https://datacatalog.worldbank.org/dataset/human-capital-index

32. United_Nations. (2018). Human Development Index. Pobrano z lokalizacji United Nations Development Programme: http://hdr.undp.org/en/content/ human-development-index-hdi

33. Wallis, A. (2006). Susuainability indicators: is there consensus among stakeholders? J. Environ.

34. Zalewski, W. (2012). Zastosowanie metody TOPSIS do oceny kondycji finansowej spółek dystrybucyjnych energii elektrycznej. Economics and Management 4/2012, pp. 138. 